\title{
Friends forever? The Role of the Visegrad Group and European Integration
}

\author{
ANDREA SCHMIDT
}

$\frac{\text { DE }}{\text { G }}{ }^{\text {DE GRUYTER }}$

Politics in Central Europe (ISSN: 1801-3422)

Vol. 12, No. 3

DOI: $10.1515 /$ pce-2016-0019

\begin{abstract}
The Visegrad Group celebrated its 25th anniversary in February 2016. Established as an initiative of three statesmen from the Central and Eastern European (CEE) region, this cooperation has experienced booms and crises. The aim of this paper is to analyse the function of this regional integration in the years following the end of bipolar system as Visegrad Group members headed down the road to Euro-Atlantic integration. To this end, I apply different theoretical approaches and attempt to explain the influence of key former politicians as well as new scenarios for the Visegrad Group's position in the European Union. This analysis also covers the latest foreign policy changes and challenges facing CEE due to the involvement of a wider region that creates a counter-balance to the core EU. Statistical data and official documents from the Visegrad Group's website strengthen these findings.
\end{abstract}

\section{Key words: regional cooperation, European Union, foreign policy}

The Visegrad cooperation celebrated its 25th anniversary in February 2016. This special type of regional cooperation was established by the three participating states from the ruins of a collapsing bipolar system. Since 1993, when Czechoslovakia was dissolved and the Czech Republic and Slovakia became independent, Visegrad has functioned as an entity with four member states. Over the last quarter century, this regional cooperation has seen booms and crises, and at times its legacy has come into question. The birth of the Visegrad Group was treated (and is sometimes still seen) as a miracle and the ultimate proof of the success of strong contributions based on common interests without any outside aid. The Group is still active, and from time to time, it causes surprises and obstacles in the European context. 
For all these positive appraisals, Visegrad has had its share of controversies. On several occasions, the necessity of this cooperation and its effectiveness have been questioned; leading politicians have put the success of the Group at risk by subordinating it to their personal ambitions. Nevertheless, these occasional common threats - along with shared goals, international events and the obstacles of everyday operations - have also deepened the cooperation. This article deals with the prospects of survival of the Visegrad cooperation. Mindful of the role of regional integration generally and in CEE in particular, I analyse various scenarios and standpoints in order to find adequate answers to the question of whether the Visegrad cooperation can still be treated as effective integration and whether, from a broader perspective, Central and Eastern Europe represents a collapsing region. My position is reinforced by statistical data regarding the position of the Visegrad cooperation; other documents related to annual presidencies also support this analysis. Lastly, in comparing the prospects of the Visegrad cooperation, I note that the survival of the Group can be explained in various ways. ${ }^{1}$

\section{Borders in Central and Eastern Europe}

Examining the past and present state of CEE cooperation - that is, the way it came to take on the form and function of Visegrad Group - confirms the historical lesson that the European continent cannot be considered a homogeneous entity; it contains cleavages which are either cultural or economic. Unsurprisingly, these two kinds of divisions are located at more or less at the same places. ${ }^{2}$ Like many others, Hungarian historians have accepted Wallerstein's (1983) model of a triply divided structure. Observing common roots and differences in the development of the CEE region, Jenő Szűcs (1981) developed an extended model to reflect internal cleavages within the European continent. According to this common view, the gap between the more developed West and the (eastern) periphery can be explained by several historical and economic factors. Both these commentators also identified a so-called semi-periphery, which can be understood as the Central and Eastern European region.

Assessing borders and cleavages raises complicated issues. The situation may become even more complex if we wish to examine the reasons and methods for border creation. The region can be seen as a special case given the fact that the

1 In a lecture in September 2016, Géza Jeszeszky, the former foreign minister of Hungary in Antall József's government of the early ' 90 s and one of the Visegrad negotiators, confessed that a lack of strict rules had perhaps been crucial for the cooperation's survival.

2 The division of Europe is a popular theme among scholars. Wallerstein's (1983) theory of the core and the periphery is based on an ideology also described by the Hungarian historian Jenő Szücs (1981) in his work Vázlat Európa három történeti régiójáról[Aside from its aspiration to provide a summary comparison of the different regions of Europe, the importance of this essay lies in its delicate timing. First published in the early 1980s, it claimed that there was no such thing as a homogenous Eastern Europe. 
final borders of the CEE states were settled in the 19th and 20th centuries while in Western Europe during the Cold War, the placement of borders remained a symbolic issue that could link people together. The problem of borders is also closely connected with how Europe is identified. According to Jacobs (2012), for example, it is obvious that "Europe" represents a concept as well as a continent. On this interpretation, Europe became virtually synonymous with Christendom during the Middle Ages. Another relatively recent if generally unaccepted theory maintains that Europe spanned half the globe, extending from Iceland to the Bering Strait and nearly touching Alaska. Religious issues remained at the core of Europe's division into smaller units, and concerns about ethnic and religious identity often surfaced in debates about the structure of the European regions.

The post-World War II period saw the creation of new concepts. The entire Central and Eastern European region belonged to the Soviet Union's sphere of interest, and it was hardly possible to discuss any kind of cultural, ethnic or even religious cleavages (Schmidt 2011). Later, in the second half of the 1980s especially, new discussions opened up about the structure of Europe. Following Huntington's (1996) theory as well as the 1930s scholarly debate between Oscar Halecki and Jaroslav Bidlo over East-West borders, ${ }^{3}$ Poland, the Czech Republic, Hungary, Slovenia, Slovakia and Croatia were deemed to be the western half of the CEE region, while Russia, Belarus, Ukraine, Bulgaria, Rumania, FYROM and parts of Bosnia composed the eastern half (Gorzelak 2002).

During the Cold War, however, the opposite tendency prevailed: all of the Soviet Union, including Vilnius, Riga and other cities that today lie within the European Union, was excluded from Europe entirely. At times, even the Soviet satellite states under the Warsaw Pact were left out, and thus, "Europe" became synonymous with the "West" and its associated political values (Schmidt 2013). The Cold War period saw widespread understanding and agreement about where the borders of a divided Europe were to be found and which ones were most important (Bialasiewicz 2009). The borders that divided Europe also divided the world. They created the geopolitical division between East and West. The Iron Curtain both divided Europe and - because this division was exported to other parts of the world - also worked as a global border.

Among the consequences of the revolutions of 1989 was a profound reordering of the spatial imaginary of Europe. The collapse of both the Berlin Wall and the Soviet bloc called for the creation of new geographical stories and new spatial representations that could capture and codify the cartographic chaos of the former Eastern European space (Bialasiewicz 2003). Although the Cold War was over, its borders did not disappear at once. The European East-West ones

3 In the interwar years, the famous Polish historian Halecki and Czech Byzantinist Bidlo had quarrelled over the place of Poland in Europe. While Halecki located the country in the east based on a simple bipartite division of the continent, Bidlo claimed it was wholly western (Okey 1992). 
were inevitably strengthened, and while in Western Europe, the role of borders declined and there was some kind of recognisable integration, to the east of the continent, the isolation of borders became even more critical. As we have seen, while the entire Central and Eastern European region fell in the sphere of interest of the Soviet Union, it was scarcely possible to reflect on any kind of cultural, ethnic or even religious cleavages or indeed any other differences among the group of socialist countries. Nevertheless, these discussions began from the second half of the 1980 s especially.

Some final points about borders should be noted here. The act of border creation can be understood to happen in one of two ways: on the first approach, the border is created from above by way of state participation and efforts in a process that usually seems rather peaceful. The peacefulness of this method is particularly clear when we compare it with the second approach whereby borders are established from outside, usually as a consequence of cataclysmic events such as a painful loss or victory on the battlefield and peace talks. It remains a crucial question whether aside from their shared acknowledgement of borders, inhabitants enclosed by state boundaries experience any kind of common identity related to the region they come from. Today, people from the Visegrad region are supposed to feel connected to several identities: these are local, regional, national, European and - last but not least - some sort of "Visegrad" or Central European identity.

\section{Cleavages in Europe and the position of Visegrad}

As we have seen, the internal cleavages or borders of Europe were a forgotten issue in the age of the Cold War. The Central and Eastern European region was treated as a homogenous entity matching Russia's so-called zone of influence. As perceived by the West, Europe ended at the Iron Curtain and everything located beyond this border was part of the group of satellite states within the Soviet Union's sphere of interest.

The question of CEE regionalism, in fact, remained complex throughout the 20 th century. The notion of a common territorial identity among citizens with different mother tongues was suppressed in state propaganda, which presented the historical regions as "actually" ancient Polish, Czech, Hungarian and Romanian lands. Moreover, the depiction of the relationship between territory and ethnicity was one dimensional, and because of socialist states' hierarchical centralism, the historical regions did not evolve into collective actors (Tägil 1999).

Turning to the progressive increase in European integration after the end of World War II, the European experience provided different models for regional integration. On the one hand, Western European integration focused on trade agreements and helped remove customs duties among member countries. By the end of 1990s, these changes had produced a deeper level of integration leading 
to the formation of a common currency area (Lee - Kim 2013). On the other, the Central and Eastern European countries saw political changes requiring the radical revamping of their trade policy and political institutions. Along with the inevitable political reforms, one noteworthy development was the considerable opening up of local markets to foreign suppliers of goods and services.

As the late 1980s became the age of debates about the division of the CEE region, new questions and problems arose. Given the political transformation and collapse of the Soviet Union, historical forces demanded the reorganisation of the spatial structure of the region. As we have noted, the 1989 revolutions brought a radical reordering of Europe's spatial imaginary (Bialasiewicz 2003). Early in the next decade, the new democracies of Poland, Hungary and Czechoslovakia, thus, set out to pursue a new mode of Central European cooperation symbolised by their formation of Visegrad Group (Ash 1999). Attempting to move past old debates and misunderstandings related to the history of this region, the political leaders of the three (later four) Central and Eastern European countries began to focus on this totally new form of cooperation. This mode of regional integration was a natural consequence of historical forces. Regional integration was useful since there was no external actor who could assist with the transformation and orientation of these countries, let alone other issues. Accepting Haas (1970) review of regional integration, the Visegrad cooperation might be seen as a good example of a process whereby nation states "voluntarily mingle, merge and mix with their neighbors so as to lose the factual attributes of sovereignty while acquiring new techniques for resolving conflicts among themselves."

Generally speaking, we can examine integration efforts in terms of eight important functions

1. Strengthening of trade integration in the region

2. Creation of an appropriate enabling environment for private sector actors

3. Development of infrastructure programmes to support economic growth and regional integration

4. Development of strong public sector institutions and good governance

5. Reduction of social exclusion and development of an inclusive civil society

6. Contributions to peace and security in the region

7. Development of environment programmes at regional level

8. Strengthening of the region's interaction with other world regions

The processes of regional integration that emerged after World War were originally most concerned with trade and economics. In contrast, the "new regionalism" wave after the 1980 s was a multi-dimensional process entailing aspects of politics, diplomacy, security and culture alongside economic cooperation. (íde 
ílombarde-Van Langenhove 2006) The end of the bipolar system and subsequent transformation years unleashed a sequence of unresolved questions in the post-socialist world. For independent states in the region, the new challenges concerned how to balance integration with a state of total or partial isolation. In creating Visegrad Group, the founding states, thus, had to focus on a very special form of integration that would reduce the meaning of internal borders while suggesting the potential for new external boundaries. The natural course of this cooperation would have been some kind of permanent institutional structure, however the founding partners concentrated on a looser approach entailing limited norms and a less institutional structure. Referring to academic analyses of regional integration (Dobson 1991), this process recalled the most intensive form of inter-state interaction with common inter-state policies. The aims of this Visegrad integration may be understood in various ways. While the Group was established partly for practical reasons, as Ash (1999) remarks, there was another explanation for this alliance:

they believed in the idea of Central Europe, which Havel and the new Hungarian president, Árpád Göncz, had preached in the 1980s, and wished to preclude any return to the petty nationalisms of [the] interwar years. But it was also because th[is] tight little regional cooperation would win their countries' favor in the West (Ash 1999; see also Schmidt 2011)

The role of the Visegrad cooperation can also be analysed by applying some of the factors set out in the general scholarship. Most crucial here is the issue of whether the regional agreements of the Group met any or all of the following criteria:

1. Consistency with domestic policy objectives ${ }^{4}$

2. Creation of incentives to reduce, minimise or eliminate trade diversion

3. Production of a deeper level of integration than what could have been achieved through the "multilateral option"

4. Enabling of a faster rate of integration with outside countries than what would have been possible under multilateral agreements (Drabek 1997)

The great challenge for CEE countries initially was moving away from traditional isolationism. The next step entailed joining or activating membership in multilateral economic institutions and encouraging various regional initiatives. Sometimes these efforts all took place at the same time.

At the outset, there was common agreement across Europe that the political objective for the CEE countries was the introduction of democracy based on a multi-party political system, respect for human rights and the principles of

4 The consistency of the Group's multilateral agreements with domestic objectives should also be considered. 
a market economy. A second common interest was security. While the collapse of the Council for Mutual Economic Assistance (CMEA) ${ }^{5}$ and the Warsaw Pact were generally welcomed, many in Central Europe believe Russia's retreat from Central Europe was only temporary. Building closer security ties to the West was, therefore, an important goal of the CEE states. A third shared interest was environmental issues. The EU had a strong interest in cooperating more closely with Eastern Europe in order to resolve a variety of environmental problems that had plagued the CEE countries for decades (Drabek 1997).

Despite the integration process, the issue of independence continued to occupy a central position. When it came to planning future cooperation, historical experience also proved very helpful. Focusing on historical roots, Vaclav Havel, the former president of Czechoslovakia put together a cooperation initiative that referred to the success of a historic meeting of Bohemian, Polish and Hungarian kings in 1335. In a message to the Polish and Hungarian prime ministers and presidents, he put it:

We should not compete with each other to gain admission into the various European organizations. On the contrary, we should assist each other in the same spirit of solidarity in which, in darker days, you protested [against] [...] our persecution as we did against yours (quoted in Lengyel - Suranyi 2013)

In initiating the cooperation, Havel aimed to break free of the isolation in which the Central and Eastern European countries found themselves after the dissolution of the Soviet Union. No longer part of the Soviet zone, these states had only just begun to confront the challenges of independence and were reluctant to give up this position and take on an Euro-Atlantic orientation (Lengyel 2006). The CEE countries were also waiting to be invited and received into the European Economic Community but in the early 1990s, there was no sign of the acceptance of their efforts. The Visegrad cooperation focused on economic, cultural and security issues but its chief task was helping member states on the transformation path. The inauguruation meeting organised by Havel took place in Bratislava in 1990; its main task was the development of a security policy since the end of the bipolar system and collapse of the Soviet Union called for a new orientation within foreign policy. ${ }^{6}$

There can be no doubt that by 2004, the ultimate goal of European and trans-Atlantic integration had been accomplished, and in economic terms, these

5 CMEA had been a Soviet Union-led system of regional integration. The dominance of the Soviet Union inevitably hampered the extension of common trade agreements among the satellite states.

6 The idea of restoring a sense of Central Europe was very popular in the late 1980s. Several conferences, meetings and publications dealt with the changing role of CEE. The Central European University was the practical result of annual conferences along these lines in Dubrovnik. The university even had its faculties in Prague (Czechoslovakia), Warsaw (Poland) and Budapest (Hungary), that is, in the countries which were the "closest to each other," creating a "geopolitically important [,] blessed and damned region where the future of Europe could be decided and solved" (Kiss Gy. 2000) 
countries also took on a Western orientation. Nevertheless, the framework for economic independence remained a key problem. In the beginning, it was obvious that the Visegrad region needed financial resources from abroad in order to help these states' ruined economies while Western European countries required extended markets in which to sell their goods. It was merely a side effect that in adapting to the principles of a market economy, this region gradually integrated market economics. Seeking new perspectives, the Czech Republic, Hungary, Poland and Slovakia agreed to establish their own sub-regional trade initiative - the Central European Free Trade Arrangement (CEFTA) - in March 1993 and they invited Bulgaria, Romania and Slovenia to join.

With the collapse of CMEA and the disappearance of the Soviet Union as the main trade partner of the majority of the CEE states, CEFTA had to guarantee economic cooperation in order to support the region, and it did this by eliminating taxes and tariffs on international commercial activity. Later, with European integration, CEFTA would lose its original members, who enjoyed tax-free trade within the European Union. The CEFTA arrangement then took on a new orientation, gradually expanding its area of interest to include other satellite and even post-Soviet states.

The Visegrad cooperation had its own special integration mission to accomplish. This was not the reconstruction of a petite entente as there was no great power working behind the scenes to control the member states or even coordinate their cooperation. Similarly, there was no push to revive the Yalta system, which was the structure that the new independent states most wished to avoid. The integration sought not to pit the states against one another but to provide a proactive tool for their cooperation. As there was no existing model for such habitual use, only limited rules were adopted. In fact, this system of cooperation remains special since it continues to lack of the following elements:

1. An organised structure.

2. Fixed and written rules of cooperation. (The system is flexible.)

3. Official headquarters. (Through a special annual rotation system, each member state takes on the tasks of the presidency every fourth year. The Czech presidency, for example, extended from July 2015 until June 2016.)

4. A strict agenda. (Annual meetings take place among different experts and sectoral policy representatives at ministerial level.)

5. More than one functioning organisation. (The Group's organisation, International Visegrad Fund (IVF), is based in Bratislava and has an annual budget of 8 billion Euro that is paid by the four member states. This is also the basis for the scholarships offered by IVF.)

This system of cooperation lacking written and fixed rules was strongly influenced by the representatives of the member states for whom the Group had 
different meanings. The general aim set out a series of action plans concerning the consequences of political and economic transformation and the new international political environment. The founding partners expressed their intention to rebuild based on the democratic framework of a new civil society and transformation into a market economy.

The success of the Visegrad Four (V4) has, thus, been based on the effectiveness of their cooperation, and this is also what may guarantee the Group's survival. The size and influence that these countries may achieve if they are united by common aims cannot be ignored. According to the data, if the V4 were a single country, then its total population of $64,301,710$ would make it the 22nd largest state in the world and the fourth largest in Europe. ${ }^{7}$ From the standpoint of economic potential, the Visegrad Group is the world's 16th-17th largest economy.

\section{Table 1: Estimated GDP in 2016}

\begin{tabular}{|c|c|c|}
\hline Ranking & Country & GDP in USD million \\
\hline & Total world & $\mathbf{7 3 , 9 9 3 , 8 3 5}$ \\
\hline 1. & USA & $18,558,130$ \\
\hline & EU & $16,477,211$ \\
\hline 2. & China & $11,383,030$ \\
\hline 3. & Japan & $4,412,600$ \\
\hline 4. & Germany & $3,467,780$ \\
\hline 5. & United Kingdom & $2,760,960$ \\
\hline 6. & France & $2,464,790$ \\
\hline 7. & India & $2,288,720$ \\
\hline 8. & Italy & $1,848,690$ \\
\hline 9. & Brazil & $1,534,780$ \\
\hline 10. & Canada & $1,462,330$ \\
\hline 11. & South Korea & $1,321,200$ \\
\hline 12. & Spain & $1,242,360$ \\
\hline 13. & Australia & $1,200,780$ \\
\hline 14. & Russia & $1,132,740$ \\
\hline 15. & Mexico & $1,082,430$ \\
\hline 16. & Indonesia & 936,955 \\
\hline & Visegrad group & 866,296 \\
\hline 17. & Netherlands & 762,521 \\
\hline
\end{tabular}

Source: Author according to http://www.imf.org/external/pubs/ft/weo/2016/01/weodata/weorept.aspx?pr. $\mathrm{x}=51$ \& pr.y=10 \& sy=2015 \& ey=2016 \& scsm=1\& ssd=1\& sort=country \& ds=.\&br=1\& c

7 This transformation of the V4 into an independent state was never on the agenda of the Visegrad Group member states. 
Table 2: Largest European Union countries by population in 2016

\begin{tabular}{|c|c|c|}
\hline Ranking & Country & Number of inhabitants \\
\hline 1. & Germany & $80,682,351$ \\
\hline 2. & UK & $65,111,143$ \\
\hline 3. & France & $64,668,129$ \\
\hline & Visegrad Group & $64,392,055$ \\
\hline 4 & Italy & $59,801,004$ \\
\hline
\end{tabular}

Source: http://www.worldometers.info/world-population/population-by-country/

\section{Extension scenarios: Visegrad Group on the road to Euro-Altantic Integration}

In the first decade of its existence, the V4 cooperation experienced several conflicts and downturns. The very first obstacle came in 1993 when the number of original founders increased with the dissolution of Czechoslovakia. Immediately after the territorial changes in 1993, the Czech prime minister, Vaclav Klaus announced that his country's aims would supersede the common interest. Klaus went so far as to suggest that the Czech Republic would no longer be interested in the Visegrad cooperation since the focus should instead be on cooperating with Western Europe (Jovanovic 1998). Klaus's view can be explained by the fact that even in the mid-1990s, he was convinced that the Czech Republic belonged to the West more than to any other formation, and he dismissed Central Europe as a geopolitical category. ${ }^{8}$ Klaus claimed that the Visegrad Group was an artificial product of the West (Lázár 2014). This position harmed cooperation with the Czech Republic's neighbours and a competition began to see who would join the EU soonest. These comments from the Czech PM also disregarded the practical reality: it would be foolish to believe that the industrial Czech Republic belongs anywhere besides Central Europe, which also includes Poland and Hungary. ${ }^{9}$

The V4 countries were not satisfied with mere association with the European Communities, and as such, in the mid-1990s, they submitted their official EU membership applications. Hungary was the first V4 country to apply for full membership, lodging its official application on 1 April, 1994. Poland officially

8 In several respects, Klaus was correct. The Czech Republic's geographical position is different from that of the other three member states. The country is located to the west of Poland, Slovakia and Hungary. While there are several models of Europe's inner borders, the location of the Czech state is generally treated as "Central" while the other three countries represent "East Central" or "Central East" Europe. At the same time, the locations given to the Visegrad Group member states are highly dependent on the expert making the pronouncement.

9 For more information, see Dostál (n.d.) 
applied for EU membership on 8 April, 1994 and Slovakia did so in June 1995. The Czech Republic made its formal application in Brussels at the beginning of 1996. At the European Council's Luxembourg summit in December 1997, a decision was reached that the Polish, Hungarian and Czech applications were ready for negotiation. As such, these three Visegrad Group states began their EU membership pre-accession negotiations together with the other Luxembourg group states (i.e. Slovenia, Estonia and Cyprus) in March 1998. During the EC's Helsinki summit in December 1999, it was agreed that Slovakia, Bulgaria, Romania, Lithuania, Latvia and Malta would also start their EU membership negotiations. Pre-accession negotiations with Helsinki Group states (including Slovakia), thus, began in March 2000 (Pawlas 2015).

Before joining the EU, the Visegrad Group members had emphasised that their strength was based on cooperation. Nevertheless, in 2002, the Polish and the Czech members took part in secret negotiations in Denmark. After European integration, the Visegrad Group contained representatives from three different groups of states: with a potential Warsaw-Berlin-Paris triangle in the pipeline, Poland found itself among the most prestigous member states while Hungary and the Czech Republic each belonged to the group of medium-sized EU member states and Slovakia represented the Visegrad Group's interests among the smallest EU members. Having been quite efficient in its negotiation process, Slovakia managed to finish its accession negotiations together with other Visegrad Group states on 13 December, 2002 in Copenhagen. The Accession Treaty between these V4 states and the EU was signed on 16 April, 2003 in Athens and they all acceded to European Union structures on 1 May, 2004. (They were joined by six other new member states, i.e. Slovenia, Lithuania, Latvia, Estonia, Malta and Cyprus, who also finished the negotiation process in Copenhagen in December 2002.) Since that time, all these states have been treated as full European Union members and have, thus, had the right to participate in creating the EU's future (Pelkmans 2006).

The first few years of the Visegrad Group's cooperation resulted in various doubts about the prospects of mutual understanding. As the V4 states checked off their final goals of transforming into market economies and achieving Euro-Atlantic integration through the acceptance of invitations to join NATO and later the European Union, new questions and cleavages emerged regarding the cooperation itself. Breakdowns and setbacks, usually attributed to ideas of solidarity and coordination being overriden by competitive attitudes and national ambitions during the EU accession negotiations, prompted many to seriously doubt the chances of the Group's survival (Lázár, 2014). Pessimistic views were shared about this highly painful if illuminating failure of Central European cooperation. In the face of these doubts, the V4 members concluded the 2004 Kroměřiž Declaration, which set out a framework and goals for future cooperation, taking account of the fact that the original V4 objectives of some 15 years 
earlier - a trans-Atlantic orientation and European integration - had now been fulfilled. ${ }^{10}$ The V4 representatives, thus, expressed their commitment to becoming ambassadors of countries awaiting integration with the European Union.

Though European integration was the ultimate proof of the legitimacy of the V4 cooperation, it also raised new concerns about the cohesion of these four countries. A key issue was the asymmetrical size and influence of the member states. In this regard, Poland emphasised its own distinct aims and interests in seeking out a position in the European Union and NATO as a strong partner to the US in the war in Iraq. This difference in Poland's position recalled an old quandary for the V4 states: Was it necessary to concentrate on political alliances, or were they better off emphasising the importance of civil platforms? Fałkowski-Bukalska-Gromadzki 2003). Here some Czech commentators maintained that instead of strengthening ties with Poland, it would be reasonable for the Czech Republic to focus on Central Europe and the historic connection with Austria and Slovenia instead (Pehe 2004). ${ }^{11}$ Czech President Milos Zeman and his Slovak counterpart, Ivan Gasparovic also discussed the prospect of enlarging the Visegrad cooperation by inviting new member states to join. While Zeman supported enlargement through the entry of Slovenia, Gasparovic opposed this move, maintaining that no conclusion had ever been reached on the expansion of the V4, a reputable and important "brand" in Europe, which should continue to cooperate according to its traditional alignment (Lázár 2014). Earlier, in 2007, Slovak Prime Minister Robert Fico had expressed the same opinion, arguing that the Visegrad Group enjoyed a high level of political "added value" and so there was no reason to enlarge it (Lázár 2014).

The view in Hungary was similar to the one in the Czech Republic, however Poland insisted that the Group take no new members. Instead of focusing on the "restoration of the Habsburg monarchy," as Polish experts usually accused

10 This declaration included the following wording: "The Visegrad Group countries regard their accession to the European Union and NATO as a significant step towards the reunification of Europe and as a historic milestone on the path of their democratic transformation, integration efforts and mutual cooperation. The integration of the Visegrad Group countries into the European and Euro-Atlantic structures opens up new opportunities and poses new challenges for their further cooperation on the issues of common interest.

The cooperation of the Visegrad Group countries will continue to focus on regional activities and initiatives aimed at strengthening the identity of the Central European region. In this context, their cooperation will be based on concrete projects and will maintain its flexible and open character."

11 This remains a live issue. In future years, the situation may become even more complex since some Czech, Hungarian and Slovak politicians would like to join in hardcore European integration in the event that European states create a two-speed Europe following the failure of the [YEAR?] Brussels summit. If some Visegrad countries commit to hardcore European integration, while others, in particular, Poland, opt out, there will be a new dividing line between these groups, which will definitely bury the Visegrad cooperation.

Whatever happens, it is time to start thinking seriously about a new way of organising Central Europe. For the Czech Republic, Hungary and Slovakia, close cooperation with Poland may not be the best route to self-protection and self-advancement in the EU since the interests of those small countries and a large and self-confident Poland may not coincide. 
their Hungarian colleagues of doing, Visegrad Group members have, thus, gradually turned east, involving the Eastern Partnership member states in the cooperation and beginning to orientate themselves towards the Balkan peninsula. ${ }^{12}$ Cooperation with the Eastern Partnership is an obvious choice since three of the four Visegrad member states share borders with Ukraine, and the "Orange Revolution" and resulting Ukrainian political instability have created new threats at eastern borders. These are also the eastern borders of the European Union, which has led to more interest in the security question.

After ten years of EU membership, the outbreak of the war in Ukraine and resulting security policy issues, including the defence of Visegrad and European Union borders, are among the most challenging concerns that the V4 and EU have had to face. This war has practically moved into the neighbourhood, calling on the states to adopt an active security policy. ${ }^{13}$

\section{Strong statesmen, weak cooperation?}

The success of the Visegrad Group has also been the result of its active politicians. In the absence of institutionalisation or any automatically binding cooperation mechanisms, the place of the Visegrad cooperation in the minds of the political leaders of the Visegrad states provides an important lead when it comes to assessing the prospects of the cooperation as well as any signs of how successful or significant the V4 actually is or might become (Lázár 2014). Personal connections and relations among prime ministers and presidents could easily affect the success or failure of the cooperation. As we have seen, the first obstacles to the Visegrad Group's cooperation emerged as a result of Vaclav Klaus's standpoint on the Czech Republic's position and orientation. Klaus formed the opinion that there was a need for CEFTA cooperation instead of dealing with a "tenth rate initiative at best" from a Polish and Czech perspective (Lázár, 2014). At a meet-

12 As we have seen, over the years, several scenarios have been put forward for extending cooperation by accepting new members. The Hungarians have made frequent reference to the "good old traditions" between Hungary and Austria and also cited Slovenia /and Croatia as potential new partners. In contrast, the Poles opposed re-establishing the Austro-Hungarian monarchy at the turn of the 21st century. This Polish preference for working with Eastern Partnership members may be explained by Polish foreign policy's Ukraine-Lithuania-Belarus (ULB) orientation. Historically, there have been special ties among these states, and Poland has felt a special responsibility towards them. Notably, these ties were disrespected by Russia

13 Based on discussions of a preliminary plan, the V4 battle group was to be placed on standby by 2016 under the Defence Austerity in the Visegrad Region (DAV4) programme. This was combined with plans to set up a long-term cyber security cooperation mechanism, a V4 + Ukraine EU battle group, common V4 air surveillance, a common air force pilot training centre and stronger cooperation among V4 defence academies. As a result of the V4's specific geographical position and opposition to illegal immigration as well as dilemmas concerning the relaxation of its visa policy for citizens of Eastern Partnership states, the Group needed to adopt a special joint refugee policy in 2015 to deal with the growing number of immigrants. This issue formed the basis for a common platform among cooperating politicians and governments. 
ing of CEFTA member prime ministers in Poznan, Poland, on 25 November, 1994, he reaffirmed his opposition to the political interdependence of Visegrad countries, claiming that Czechs were only willing to cooperate on trade matters within a CEFTA framework. At the meeting's final press conference, he went so far as to say that the Czech Republic now translated "Visegrad" as "CEFTA" in its internal dictionary. Klaus denied that there was a lack of cooperation in this region; instead, he contended that the Czech Republic was the "driving force" behind the economic cooperation embodied in CEFTA. In response, the Polish president, Lech Walesa accused him of elevating Czech interests above those of Visegrad Group (Fawn 2005). By 2011, Klaus's view had changed considerably and he remarked that the Visegrad cooperation had contributed to strengthening the friendship among the four countries. Concerning his previous position, he claimed that he had only rejected the idea of the V4 replacing fully-fledged national membership of Western institutions when Western partners had hesitated to promise EU and NATO membership to the four countries. After EU accession, however, the V4 had acquired a new foreign political dimension and this permitted the formulation of joint interests and priorities as well as their promotion at international level (Lázár 2014).

The former Slovak Prime Minister Vladimír Mečiar was not a Visegrad fan either. The Slovak challenge to Visegrad was also ideological but had different content. The nationalistic Mečiar antagonised the Hungarian minority in Slovakia, damaging relations with Budapest. His regime's foreign policy also moved away from Euro-Atlanticism and even made surprising overtures to Russia (Harris 2010). Mečiar's attitude hampered Slovak participation in the Visegrad cooperation between 1994 and 1998. Eventually, he also concluded that "in the end, sooner or later we will have to cooperate together" (Harris 2010). Despite these tensions, internal communication in Visegrad continued to function, demonstrating the Group's basic viability. As we have seen, Visegrad Group members entered the European Union together, a development that might be understood as the ultimate sign of their Western orientation. Nevertheless, this achievement also called into question the very grounds for the cooperation's existence. The Visegrad cooperation has frequently been compared with the situation of the Benelux states. While the Group admittedly lacks the internal unity of the Benelux Union, it has repeatedly succeeded in presenting a more or less united position within the European Union, which is a far better outcome than if its members were competing with each other. ${ }^{14}$ Even so, the late 1990s saw the eruption of a crisis in the Group. Along with Vladimir Mečiar's views, Hungary's Orbán government of the late 1990s had the effect of weakening the cooperation. Slovak-Hungarian relations had always been seen as a weak point in the Group.

14 This opinion was also expressed by former Hungarian foreign affairs minister Geza Jeszenszky on the 25th anniversary of the establishment of the Visegrad cooperation. 
From the perspective of FIDESZ, Hungary's governing party, it was vital that the country's foreign policy focus on advancing Hungarian interests. In 1998, when Orbán was invited to Washington, it had already been announced that Hungary, Poland and the Czech Republic would join NATO in the near future while Slovakia might be invited later on. In 1999, the European Union added that Estonia, Poland, the Czech Republic, Hungary, Cyprus and Slovenia were the first six states chosen to begin European integration negotiations. It was also noted that these negotiations might be protracted for as long as a decade. ${ }^{15}$ This decision gave Orbán's government a new impetus to focus on strengthening regional diplomacy, including the renewal of the Visegrad cooperation and reinforcement of ties with Austria in April 2000. ${ }^{16}$ Orbán declared his aims in a speech to the Hungarian national assembly in November of that year:

With all our efforts, we have to try to take part in the cultural, political and economic re-structuring of Central and Eastern Europe. We have to treat the neighbouring countries as our partners in the creation of a common Central European future. This was our intention when we concentrated on the renewal of the Visegrad cooperation beginning with the negotiations with Poland and Czech Republic, then with Slovakia after the elections (quoted in Gavra 2003)

The first obstacles to this renewed cooperation came with a statement by Orbán on the incompatibility of the existing Benes decrees with European integration and the need to adapt to the EU legal system. This issue was seen as unacceptably sensitive and, as a result of Orbán's comment, a meeting of Visegrad Group prime ministers scheduled for Budapest in 2002 was suspended when Czech and Slovak partners refused to participate. The frozen relations between Slovakia and Hungary gradually thawed, and in 2013, Slovak Prime Minister Robert Fico and Orbán spoke of "opening a new chapter in the shared history of the two countries," claiming that the relationship between the two states was based on "political and personal trust" (Lázár 2014). ${ }^{17}$ In the same year, Slovak Foreign Affairs Minister Miroslav Lajcak added that "Visegrad is going strategic, we are more mature. Visegrad makes each of us individually and as a group stronger." 18

Analysing the role of Visegrad Group member representatives more closely, it is clear that these politicians have generally hesitated about whether to refer

15 http://www.europarl.europa.eu/summits/hel1_en.htm

16 For more information, see Gábor Gavra (2003): A kormányzó FIDESZ és az EU csatlakozás: igenek és nemek, Magyar Narancs, http://magyarnarancs.hu/belpol/a_kormanyzo_fidesz_es_az_eu-csatlakozas_ igenek_es_nemek-62225

17 As Lázár (2014) remarks, Fico's personal position appeared to change after 2006 when he first participated in a meeting of relevant parties. This seems to have been a formal meeting without substantive content. By 2013, the relations had progressed to pragmatic rational cooperation with the participating countries making informed and important decisions.

18 http://www.globsec.org/globsec2013/highlights-news/globsec-visegrad-makes-us-stronger-said-lajcak/ 
to national sovereignty or express anti-EU sentiments. Orbán and his Slovak counterpart Robert Fico have long drawn on sovereigntist narratives while the Czech Deputy Prime Minister Andrej Babiš has often also resorted to anti-EU rhetoric. The famous statement of former Polish foreign minister Radek Sikorski "I fear German power less than...German inactivity" might, thus, be adapted to reflect the positions of some Visegrad leaders: "We fear German power and do not care about EU inactivity." 19 There are various reasons for this standpoint. Leaving aside the political culture of these states, we can see from the traditions of Visegrad Group that this region's convergence with the core European Union can also affect public opinion. Politicians have always sought to understand the demands of their citizens, attempting to identify with their feelings and make sense of their fears. These demands and fears appear to have been widespread, and although prime ministers and presidents have represented different political parties with different priorities, they have easily managed to find common ground on certain issues.

\section{Table 3: Party divisions among Visegrad Group political leaders}

\begin{tabular}{|c|c|c|c|}
\hline \multirow{2}{*}{ State } & \multicolumn{2}{|c|}{ Politician } & \multirow{2}{*}{ Party } \\
\hline & Prime Minister & President & \\
\hline Hungary & Orbán, Viktor & Áder, János & $\begin{array}{l}\text { FIDESZ (Hungarian Civic Alliance) } \\
\text { - conservative, nationalist }\end{array}$ \\
\hline Poland & Szydlo, Beata & Duda, Andrzej & $\begin{array}{l}\text { Law and Justice (PiS) - } \\
\text { right-wing, nationalist-conservative }\end{array}$ \\
\hline Czech Republic & Sobotka, Bohuslav & Zeman, Milos & $\begin{array}{l}\text { Czech Social Democratic Party } \\
\text { - left-wing, social democratic }\end{array}$ \\
\hline Slovakia & Fico, Robert & Kiska, Andrej & $\begin{array}{l}\text { Direction - Social Democratic (Smer) - } \\
\text { left-wing, populist/independent }\end{array}$ \\
\hline
\end{tabular}

Source: Edited by the author

This varieties of self-representation of the Visegrad states and their frequent attempts at self-determination may have added to their differences. Nevertheless, there have also been common threats which have eliminated these conflicts and forced V4 states to focus on practical solutions. The 2009 energy crisis demonstrated the gas dependency of the Visegrad member states. These countries' home production falls far short of the volume needed for sufficient consumer supplies and their gas and other energy imports rely primarily on one country: Russia. ${ }^{20}$

19 http://carnegieeurope.eu/strategiceurope/?fa=62423 http://pl2011.eu/en/content/minister-radoslaw-sikorski-visit-berlin

20 http://www.visegrad.info/energy-security-infrastrucutre/factsheet/energy-security-of-visegrad-region. html 
The priorities of each presidency have, thus, included collaboration on energy, the Eastern Partnership project, defence cooperation and the development of a digital economy. Other important topics are transport infrastructure development, the social dimension of European integration and the fight against tax evasion. The crisis in Ukraine in 2014 and the acceptance of the embargo against Russia have shown that member states' interests may vary. While Polish foreign policy has tried to ensure Poland avoids all cooperation with Russia, Hungary has made moves to strengthen ties through economic cooperation. At a meeting of prime ministers in Bratislava in May 2014, the Polish prime minister expressed his negative standpoint to the Hungarian partner, claiming that the V4 cooperation is more than a symbolic representation of a common past and future and the threats from Russia cannot be ignored. Hungary's position on the question facing the new Ukrainian government about whether to give "full collective rights" and dual citizenship to Hungarians living in the Zakarpattia Oblast has also impeded the chances of agreement among the Visegrad Group member states and Ukraine. Orbán has himself expressed his support for maintaining the territorial integrity of Ukraine; in the context of the Ukrainian-Russian conflict, this aligns with Russian rhetoric since it suggests that the government in Kiev is undemocratic and guilty of discriminating against ethnic minorities in Ukraine (Sadecki 2014). Orbán has also been blamed for the pending Hungarian position on the Ukrainian-Russian conflict. Although Hungarian diplomats co-authored both the Visegrad Group and EU declarations which condemned the annexation of Crimea by Russia and supported Ukraine's sovereignty and territorial integrity, as Sadecki (2014) points out, the Hungarian prime minister has emphasised Hungary's neutrality as regards the Ukrainian-Russian conflicts and tried to avoid any friction in relations with Russia since Hungary is in the process of building closer cooperation with the energy sector.

Notwithstanding this situation, the year 2015 saw important changes in the bilateral relations between Poland and Hungary when after eight years of governance, Poland's Civic Platform party (Platform Obywatelski, PO) lost the country's presidential and the parliamentary elections; these were both claimed by the Law and Justice party (Prawo i Sprawedliwość, PiS) in October 2015. After an extended period of controversial relations between Poland and Hungary, the new governing party and Hungary's FIDESZ have, thus, revived their friendship. While the issue is critical, the Hungarian attitude to Russia remains almost the only point of conflict between the two party leaders. The landslide victory of Poland's conservative PiS has allowed the new political elite in Warsaw to make changes at an unprecedented pace. Though Polish-Hungarian relations have reached a new peak after the change of Polish government, both states have become and remain targets for the European Union. Criticism of government policies from Brussels only adds fuel to the fire and may strengthen the posi- 
tions of Eurosceptic hardliners within PiS, who believe that Central Europe has to find its own path to prosperity, and this should not be based on catching up with Western Europe.

\section{The ultimate proof: European integration}

As we have noted, the V4 member states all joined the European Union in 2004. By taking this step, they were able to actively shape the future of European integration. Visegrad Group representatives work in all EU institutions - the Council of the European Union, the European Council, the European Commission and European Parliament as well as in the Committee of the Regions, the Economic and Social Committee, the Court of Justice of the EU, the General Court and the Court of Auditors. Moreover, this European integration has played an important role in their economic development. The V4 states joined the European Union as relatively poor countries, characterised by their low level of per capita GDP when compared to the rest of the EU (especially the EU15 countries). EU transfers today provide an important injection into the economies of the Visegrad Group countries, however the reality is far from the expected convergence. While the financial support of the new member states has been critical, the data suggests that there has been no narrowing of the gap between Visegrad Group and the most developed EU member states.

\section{Table 4.}

\section{GDP in EUR bn}

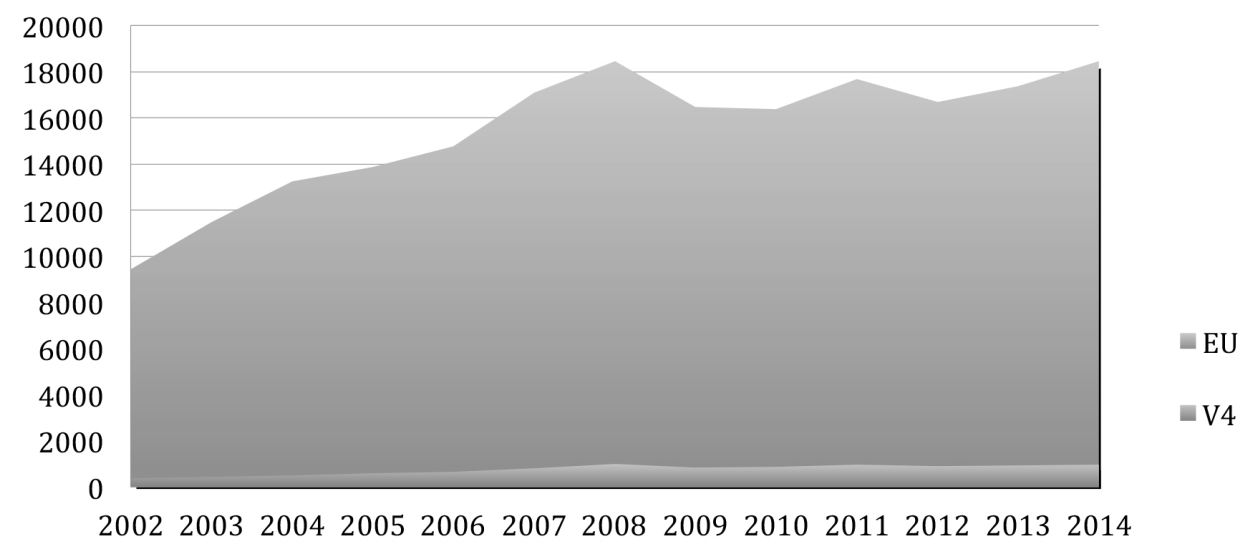

Source: IMF, http://index.hu/chart/2014/04/30/erre_jutottunk_a_sok_eu-s_penzzel/ 
Responsibility for the Council of the European Union presidency is seen as an important aspect of EU membership. According to the official presidential calendar, the Czech Republic was the first V4 member state to play this role, which it occupied between January and June 2009. The country also co-operated closely with France and Sweden in a presidency trio. The three priorities of the Czech presidency were the economy, energy and external relations. Here, a competitive and open Europe was treated as a crucial goal, with the Czechs emphasising the need to deepen the internal market by enhancing the four freedoms and improving innovation policy management. Regarding energy and climate change, the Czech presidency focused on energy security, including improving the reliability of supplies and the creation of an external energy policy. Finally, in the area of external action to the EU, the areas promoted were Euro-Atlantic relations, the Eastern Partnership, openness and further enlargement of the European Union (Drulak 2008).

Hungary was the second V4 state to take on the EU Council presidency. The Hungarian presidency occurred between January and June 2011, constituting a presidency trio together with Spain and Belgium. The Hungarian presidential agenda focused on four main topics: growth and employment through the preservation of the European social model (small and medium enterprises, demographics and family policy and the fight against poverty); a stronger Europe (food, energy, water initiatives); a citizen-friendly European Union (implementation of the Stockholm Programme; promotion of cultural diversity in the EU); and finally, enlargement and neighbourhood policy (Croatia and the Western Balkans, the Eastern Partnership). ${ }^{21}$

In late June 2011, Hungary handed over the presidency to Poland, which, presided over the EU Council from July to December 2011 and formed a presidency trio with Denmark and Cyprus. Among the priorities of the Polish presidency were the EU's exit from crisis; the EU and its external partners/neighbourhood (construed as the reinforcement of the Eastern Partnership and EU expansion) and finally, the safety of Europe (to be implemented through the EU's common security and defence policy and external energy policy) (Pawlas 2012).

In line with the presidential timetable, Slovakia has led the EU during the second half of 2016, comprising a presidential trio with the Netherlands and Malta.

It would seem that the priorities of the V4 states have been closely determined by the internal and external challenges facing the European Union. It must, however, be pointed out that these priorities have been partly derived from the specific internal problems and geopolitical location of each V4 state. Among other things, the war in Crimea has called into question attitudes to Russia, and the region's economic policy has been affected by the embargo on

21 http://www.eu2011.hu/priorities-hungarian-presidency 
Russian products since August 2014. Visegrad Group members have accepted this restriction ambivalently given the effects on energy security: after all, all these states were dependent on gas supplies from Russia and a huge share of their export activity focused on the Russian market. ${ }^{22}$

The refugee crisis has led to a renaissance of the Visegrad Group as the threat of an increasing number of migrants from the south-east has required a coordinated reaction. The Hungarian prime minister was the first to argue for prioritising national interests, and this standpoint was soon taken up by the three member states. In February 2016, the states made a joint declaration concerning a common security policy, closer cooperation with Romania, Bulgaria and Macedonia and the plan to stop the refugees at Greece's borders. A so-called line of defence was to be set up under this agreement. Andrzej Duda, the Polish president has also drawn attention to the increasing power of the Visegrad Group based largely on the migration crisis. Moreover, Zeman and Duda have agreed on the importance of strengthening ties with northern and southern states in the CEE region.

Under the new Polish government, the country's foreign policy has taken on a new approach. Instead of the old Ukraine-Lithuania-Belarus (ULB) orientation, Duda has addressed these states from a new direction based on the Adriatic Sea, Baltic and Black Sea (Czarne morze) triangle. This idea, known as the ABC policy, has received support from the Baltic states. ${ }^{23}$ The strengthening of ties among these target regions was confirmed by the visits of the Polish president to relevant areas in the first half of 2016. This development has special importance since it was greatly influenced by the migration crisis. ${ }^{24}$

Faced with the Ukrainian crisis and growing fears of Russia's actions as well as the knowledge that certain core EU members might not resist Russian aggression firmly in the Black Sea and Baltic regions, Poland has gone looking for a regional counterweight. The country has, thus, returned to the geopolitical concept of the "Intermarium," a plan for a military alliance across the Baltic, Black and Adriatic seas that was intended to counter Bolshevik and Stalinist expansion in the 1920s and 1930s. ${ }^{25}$ For President Andrzej Duda, who came to office in May 2015, this Intermarium-resembling project is a foreign policy goal. This situation has opened up a new path for cooperation, and the result-

22 As EU members, the Visegrad states have also struggled with the supply of agricultural products. In one example, tonnes of unsold apples have remained in Poland while Russian zoos suffer a shortage of apple supplies. While this may seem like a marginal concern, the Polish government has had to deal with the difficulties of both farmers and traders.

23 http://www.president.pl/en/news/art,122,president-starts-official-visit-to-hungary.html

24 When considering future scenarios for the Central and Eastern European region, Poland's geopolitical ambitions are critical. As Kraev(2016), notes, the Intermarium, a forgotten idea introduced in inter-war Poland, has been reborn in the new foreign policy of the Law and Justice Party that provides scope for wider cooperation beyond the framework of Visegrad Group.

25 http://neweasterneurope.eu/articles-and-commentary/1976-warsaw-pivots-to-the-black-sea 
ing response of Visegrad states to EU initiatives has worried many actors. As a consequence, Italian Prime Minister Matteo Renzi has warned V4 members that their EU funds will be suspended if they are not willing to accept EU rules and regulations. Back in the autumn of 1991, there was a general view within the EU that "ideas in the [Visegrad] proposal fully corresponded to their ideas for further development of cooperation between the Alliance and Czechoslovakia, Poland and Hungary." 26 Nowadays, this has changed to a perception that "Visegrad is like a bad word." 27

From time to time, a question has also arisen about whether there is a real threat that Visegrad Group may obstruct the European Union's decision-making. In this regard, it is highly relevant whether the Group remains an entity with four member states or it opens up to absorb more states. The role of this cooperation also often comes into question. $\mathrm{V} 4$ supports usually agree that the Group will remain a cohesive bloc at EU level on some key issues such as energy and migration.

On the question of their position within the European Union, it is clear that V4 countries are now being taken more seriously than they were previously. This is partly because of these states' opposition to EU migration policy, an area where common EU policies have failed to deliver results. In part, this failure reflects the reluctance of member states, who are the main parties responsible for implementation. The old methods by which strong member states pushed through policies have also created a backlash. ${ }^{28}$ After the EU summit in June 2016, Viktor Orbán echoed these sentiments, telling reporters that the EU's democratic legitimacy could only come from member states:

We have to return to the notion that the basis of the EU is not its institutions, but its members. The democratic feature[s] of the EU can only be reinforced through the member states, and the relationship between the institutions and member states must be improved. ${ }^{29}$

There is a feeling within Brussels institutions that a stronger V4 might also mean greater nationalism, populism and even xenophobia in Europe. In a media report published in September 2016, one senior EU official put it, "If you let the

26 Former German politician Hans-Dietrich Genscher made this remark about the Visegrad cooperation at a meeting of foreign ministers in Krakow, Poland in November 1991. See Spero 2004: 267.

27 See the comments of Central European Policy Institute expert Milan Nic in January 2016: http://www. economist.com/news/europe/21689629-migration-crisis-has-given-unsettling-new-direction-old-alliance-big-bad-visegrad

28 Exemplifying these methods, French President Francois Hollande scheduled a visit to Central Europe in 2016 to promote European policies as part of a symbolic reaching out to the "East." This trip was later cancelled after the terrorist attack in Nice in July 2016.

29 http://www.visegradgroup.eu/brexit-could-amplify-the 
Poles gang up with Orbán and lead the contributions at the Bratislava summit, then we are doomed." ${ }^{30}$ This comment partly referred to the current Warsaw government, which has come under heavy criticism from the EU Commission and European Parliament. ${ }^{31}$ The same official also argued that EU institutions and Western member states had to take Central Europe more seriously than in past years while also working more closely with Slovak Prime Minister Robert Fico and his Czech counterpart Bohuslav Sobotka, who are the "more reasonable" V4 members: "They [Fico and Sobotka] need our gestures. It is that moment. Thinking you can go to Bratislava, having made your call to Berlin, is not enough." ${ }^{2}$

Regarding the potential of V4 members to obstruct voting at the Council of the European Union session, current rules dictate that a blocking minority must include at least four Council members who together represent more than $35 \%$ of the EU population..$^{33}$ The extended cooperation among Visegrad Group, the Baltic states and countries in the Black Sea region represents a combined 102 million citizens, however to block the member states' actions effectively, a population of 178 million citizens is required. The Visegrad Group and members of the $\mathrm{ABC}$ countries are, thus, still too weak to paralyse the European Union's decision-making process though they may cause problems. Assuming that these states had a common cause with at least one bigger and one smaller member state, they could hamper the work of the Council of the European Union.

Concerning the future of EU integration, the expectations of V4 are quite diverse and fragmented. While the Poles and Czechs foresee expect more differentiated (multi-speed) integration, the Hungarians believe that the larger member states will dominate increasingly and the Slovaks - the only Eurozone country in the group - anticipate a reinforcement of the Euro area.

33 http://www.consilium.europa.eu/en/council-eu/voting-system/qualified-majority/ 
The $A B C$ states

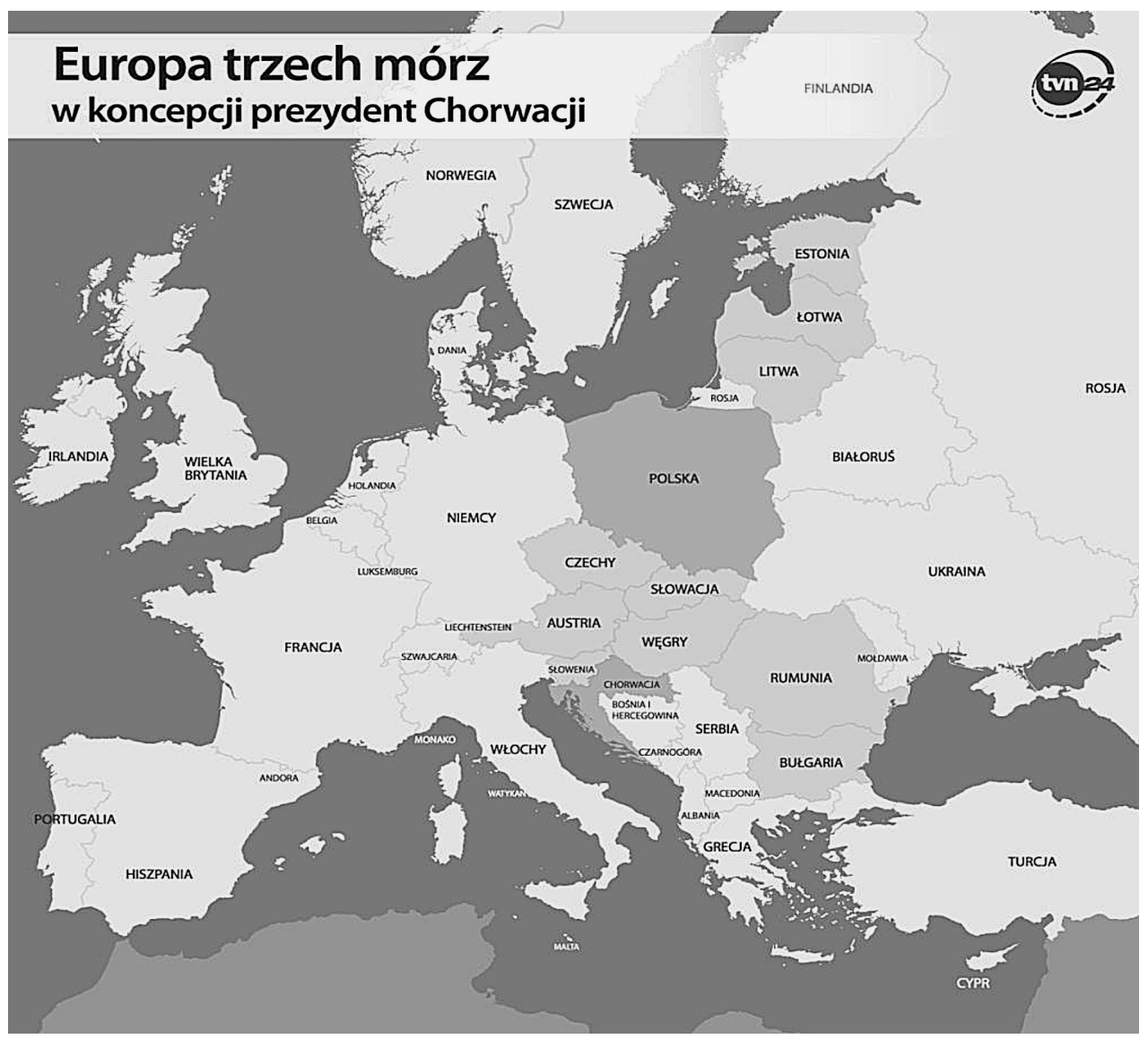

Source: http://www.tvn24.pl/magazyn-tvn24/abc-sen-o-potedze-krajow-trzech-morz,25,571 
Table 5: Share of ABC states within the European Union

\begin{tabular}{|c|c|c|}
\hline & State & Population in thousands (2015) \\
\hline 1 & Bulgaria & 7.202 \\
\hline 2 & Croatia & 4.225 \\
\hline 3 & Czech Republic & 10.538 \\
\hline 4 & Estonia & 1.313 \\
\hline 5 & Hungary & 9.855 \\
\hline 6 & Latvia & 1.986 \\
\hline 7 & Lithuania & 2.921 \\
\hline 8 & Poland & 38.005 \\
\hline 9 & Romania & 19.870 \\
\hline 10 & Slovakia & 5.421 \\
\hline 11 & Slovenia & 2.062 \\
\hline & Total & 103.498 \\
\hline & EU 28 total & 508.293 \\
\hline & Share of $A B C$ countries related to EU28 & $20.36 \%$ \\
\hline
\end{tabular}

Source: https://europa.eu/european-union/about-eu/countries_en

The refugee crisis opened up new chapter in the Visegrad cooperation. If the response to the embargo against Russia divided the member states, then the fear of the growing number of immigrants helped them to strengthen and deepen their cooperation. Public opinion and politicians' standpoints were quite closely aligned within the Visegrad member states. The Czech public was roundly opposed to taking in asylum seekers, while Milos Zeman, the country's populist president, claimed that the integration of Muslim refugees was "practically impossible." ${ }^{34}$ Anti-migrant sentiment, thus, unified the Visegrad Group of Hungary, Poland, Slovakia and the Czech Republic. Hungary's Viktor Orbán had already demonstrated the position of himself and his government in the late summer of 2015, and in an October 2016 referendum, he hoped to win the support of Hungarian voters as well. ${ }^{35}$ A similar standpoint may be expected from Polish politicians such as Jarosław Kaczyński, the leader of the Law and Justice Party and a great supporter of Orbán's policy.

Regarding the future of the Visegrad cooperation and its relations with the European Union, the increasing support for nation states and the fragility of the Union itself may still lead to unpleasant incidents. As the Hungarian ambassador to Italy, Péter Paczolay explained in February 2016 at the conference in

34 In the past year, the country has accepted just 520 of these refugees. http://www.economist.com/news/ europe/21689629-migration-crisis-has-given-unsettling-new-direction-old-alliance-big-bad-visegrad

35 The results of this referendum are beyond the scope of this study, and thus, we need only note that participation in this referendum did not reach the expected threshold. Only $43 \%$ of the population took part. Nevertheless, the results showed that the majority (98\%) of participants wished to stop these migrants at Hungary's borders. 
Forli organized for students, the Visegrad cooperation can be treated as a form of "practical solidarity," but this may be counterbalanced by the culturally and historically determined need to preserve the regional self-perceptions and identities of these four states. ${ }^{36}$

\section{Conclusion}

The Visegrad cooperation has a unique position in the Central and Eastern European region. The basis of the group is an almost six century-old history of cooperation. The cooperation has survived its years of greatest uncertainty and it has managed to overcome obstacles and threats. The founding states stood on different sides at the peace summits following the two world wars, however after 1945, they were forced to remain in the Soviet bloc. During the Cold War, they faced the challenges of belonging to a non-existent Central Europe and being isolated from Western civilisation, and there may be a common sense of recovery of a sunken history that the cohesion of these states helps to address.

Looking back over the centuries, we can see that this part of Europe was always the playground of the great powers, and the survival of these states was strongly influenced by their ability to co-operate. European integration and NATO membership were the ultimate proof of the Western orientation of the Visegrad states, and the Visegrad Group has also served as a kind of litmus paper or testing ground for the European Union. Remaining alone after the collapse of the bipolar system, the three (later four) countries had to focus on self-determination. The Visegrad cooperation framework that has survived for the last 25 years was developed, then, based on the methods current when the Central European region states were already dealing with the problem of being satellite states of the Soviet Union, but they had not yet accepted the norms and rules of an integrated Europe. The euphoria of sovereignty and independence has sometimes hampered and continues to obstruct acceptance of the EU's operating institutional framework; instead of conforming, these states have shown a tendency to propose new norms that may inevitably shock the older member states and their diplomats. Even so, given their geopolitical position and the potential advantages they can demonstrate over the other former socialist states, these V4 members have managed to preserve their importance and position in the European context. Concluding our investigation, we may, thus, note that this special type of regional integration has survived a great deal and may now serve as a model for other partnerships. As Martonyi Janos, the former Hungarian foreign minister puts it:

36 http://www.pecob.eu/flex/cm/pages/ServeBLOB.php/L/EN/IDPagina/4943/UT/systemPrint 
V4 is an ad hoc reaction to a very concrete situation and for preparations for NATO. We had to ask who we were. We are all Central Europe, and V4... is not only [a] regional operation, it is based on specific historical and spiritual identity that we now call Central Europe. ${ }^{37}$

\section{References}

Ash, T.G.: The Puzzle of Central Europe http://www.visegradgroup.eu/the-visegrad-book/ash-timothy-garton-the

Bialasiewicz, Luiza (2003): Another Europe: Remembering Habsburg Galicia. Cultural Geographies, vol. 10 pp. 21-44

Bialasiewicz, Luiza (2009): Europe as/at the border: Trieste and the meaning of Europe. Social and Cultural Geography, vol 10(3). pp. 319-333

Big, Bad Visegrad (2016, Jan 30): The Economist: http://www.economist.com/news/ europe/21689629-migration-crisis-has-given-unsettling-new-direction-old-alliance-big-bad-visegrad

De Lombaerde -Van Langenhove Indicators of regional integration, conceptual and methodological aspects, In: ed. De Lombaerde: Assesment and Measurement of Regional Integration, Routledge, Lomdonand New York, 9-42 Dobson, W. (1991): Economic Policy Coordination: Requiem or Prologue? Policy Analyses in International Economics, vol 30.

Dostal, Vit (n.d.): Debating V4: A Czech Perspective http://www.cepolicy.org/publications/ debating-v4-vit-dostal

Drabek, Z. (1997) Regional and Sub-Regional Orbán in Central and Eastern Europe: an Overview, in Regionalism and the Global Economy: The Case of Central and Eastern Europe. Fondad: the Hague, www.fondad.org

Energy Security of Visegrad region (n.d.) Visegrad.info.com, http://www.visegrad.info/energy-security-infrastrucutre/factsheet/energy-security-of-visegrad-region.html

Fałkowski, Mateusz - Bukalska, Patrycja - Gromadzki, Grzegorz (2003): Yes to Visegrad, In: Analyses \& Opinions, No. 16, Instytut Spraw Publicznych, Warszawa,

Fawn, Rick (2005): The Czech Republic: A Nation of Velvet, Routledge

Gavra, Gábor (2003): A kormányzó FIDESZ és az EU csatlakozás: igenek és nemek. Magyar Narancs, 2003/4 http://magyarnarancs.hu/belpol/a_kormanyzo_fidesz_es_az_eu-csatlakozas_igenek_es_nemek-62225

Gorzelak, Grzegorz (2002): New Models of Polish Regional Policy in a Decentralized State, EUROREG, Warsaw University.

Gyarfasova - Meseznikov (2016): Twenty-five years of the V4 as seen by the public. Institute for Public Affairs, Bratislava 15-29

37 http://www.globsec.org/globsec2013/highlights-news/globsec-visegrad-makes-us-stronger-said-lajcak/ 
Haas, E.B.: The Study of Regional Integration: Reflections on the Joy and Anguish of Pretheorizing, In: International Organization, Vol. 24, No. 4. 609-610

Hans-Ake Persson (1999): Viadrina to the Odera-Neisse Line: Historical evolution and regional cooperation, in Tagil, Sven, ed.,Regions in Central Europe, Hurst \& Company, London.

Harris, Erika (2010): Slovakia since 1989, in Ramet, S, ed., Central and Southeast European Politics since 1989, Cambridge: Cambridge University Press. 182-203

Helsinki European Council (1993, 10 and 11 December): Presidency Conclusions. European Parliament, http://www.europarl.europa.eu/summits/hel1_en.htm

Horel, Catherine (2011): A középnek mondott Európa, Akadémiai Kiadó pp. 354-365

http://www.globsec.org/globsec2013/highlights-news/globsec-visegrad-makes-us-stronger-said-lajcak/

http://www.wordometers.info/world-population/population-by-country

IMF World Economic Outlook Database, http://www.imf.org/external/pubs/ft/weo/2016/01/ weodata/index.aspx

Jacobs (2012): Where is Europe? http://opinionator.blogs.nytimes.com/2012/01/09/where-is-europe/

Jovanovic, Miroslav (1998): International Economic Integration, Taylor \& Francis

Kazimierczak, Rafal (n.d.): Magazyn TVN24, http://www.tvn24.pl/magazyn-tvn24/abc-sen-opotedze-krajow-trzech-morz,25,571

Kiss Gy. Csaba (2000): Közép-Európa, nemzetek, kisebbségek, Pesti Szalon Kiadó

Kraev, Kamen (2016, 28 April): Warsaw Pivots to the Black Sea. New Eastern Europe: http:// neweasterneurope.eu/articles-and-commentary/1976-warsaw-pivots-to-the-black-sea

Lázár, Andras (2014): Post-EU-Accession Visegrad Cooperation - Results, Rhetoric, Prospects. Biztpol Affairs, 22-44.

Lee, Jeong Yeon - Kim, Doyeon (2013): Different Models for Regional Integration: Lessons from Total Factor Productivity in Europe, ABDI Working Papers, No. 452, https://think-asia. org/bitstream/handle/11540/1212/2013. 12. 13.wp452.different.models.regional.integration. pdf?sequence $=1$

Lengyel, László - Suranyi, György (2013): Határátkelés, Kalligram, Budapest-Pozsony

Lengyel, László (2006): Illeszkedés vagy kiválás?, Osiris, Budapest. 159-161

Nic, Milan - Dostal, Vit (2016, 8 Jan): Central Europe's Outlook on the EU and Foreign Policy. Carnegie Europe, http://carnegieeurope.eu/strategiceurope/?fa=62423

Nicolo, Fasolo - Pilloni, Manuela (n.d.): The Visegrad Group between Identity and Post-Socialist Transition - Relations with the EU and contemporary crisis: Portal on Central Eastern and Balkan Europe: http://www.pecob.eu/flex/cm/pages/ServeBLOB.php/L/EN/IDPagina/4943/ UT/systemPrint

Okey, Robin (1992): Central Europe/ Eastern Europe: Behind the Definitions. Past and Present, the Cultural and Political Construction of Europe No. 137: 102-133 
Pawlas, Iwona (2015): The Visegrad Countries and European Union Membership, Selected Issues, https://www.google.hu/webhp?sourceid=chrome-instant \& ion=1 \& espv=2 \& ie=UTF$8 \# q=$ Pawlas\%2C+lwona+(2015)\%3 A+The+Visegrad+Countries+and+European+Union+Me mbership

Pelkmans, Jacques (2006): European Integration, Methods and Economic Analysis. Financial Times Management

President of Republic of Poland (2016, 17 March): President starts official visit to Hungary, http:// www.president.pl/en/news/art,122,president-starts-official-visit-to-hungary.html

Sadecki, Andrzej (2014): Hungary's stance on the Ukrainian-Russian conflict. Osrodek Studiow Wschodnich im Marka Karpia, www.osw.waw.pl

Schmidt, Andrea (2011): The Eastern Borders of Europe - Symbolic, Historical and Cultural Aspects, in Tuka -Tarrosy, eds., Borderless Europe - Changes, Opportunities, Publikon:Pecs, 39-54

Schmidt, Andrea (2012) : Piast vagy Jagello? Lengyelország és Európa, in Bretter - Glied - Vörös, eds., Az elkötelezett tanító, IDResearch/Publikon: Pécs, 119-127

Schmidt, Andrea (2013): The consequence of the EU enlargement, the new borders of the European Union in Milford, Susan - Tarrósy, István, eds. Challenges for the European Union in the next decade, 61-76

Publikon: Pecs

Spero, Joshua (2004): Bridging the European Divide (Middle Power Politics and Regional Security Dilemmas), Rowman \& Littlefield Publishers.

Szűcs, Jenő (1981): Vázlat Európa három történeti régiójáról, Történelmi Szemle, vol.3. 313-359 Tagil, Sven, ed., Regions in Central Europe, Hurst \& Company, London

Andrea Schmidt (PhD in Political Science) is a graduate of the University of Pecs, Central European University, State University of New York (Albany, USA) and Budapest Business School. She is an assistant professor in the Department of Political Science and International Studies at University of Pecs and current visiting lecturer at Ivan Franko National University (Lviv, Ukraine). She is also a former visiting lecturer at Josai International University (Tokyo, Japan) and the Polish University Abroad (London, UK). Andrea's work focuses on international political economy and comparative political studies in the Central and Eastern European region. She is the author of several articles and book chapters related to CEE and the post-Soviet region.E-mail: schmidt.andrea@pte.hu. 